\title{
Pressure and temperature dependence of the decomposition pathway of $\mathrm{LiBH}_{4}$
}

\author{
Yigang Yan, ${ }^{a} a$ Arndt Remhof, ${ }^{a}$ Son-Jong Hwang, ${ }^{b}$ Hai-Wen Li, ${ }^{c d}$ \\ Philippe Mauron, ${ }^{a}$ Shin-ichi Orimo ${ }^{e}$ and Andreas Züttel ${ }^{a}$
}

\author{
Received 13th January 2012, Accepted 7th March 2012 \\ DOI: $10.1039 / \mathrm{c} 2 \mathrm{cp} 40131 \mathrm{~b}$
}

The decomposition pathway is crucial for the applicability of $\mathrm{LiBH}_{4}$ as a hydrogen storage material. We discuss and compare the different decomposition pathways of $\mathrm{LiBH}_{4}$ according to the thermodynamic parameters and show the experimental ways to realize them. Two pathways, i.e. the direct decomposition into boron and the decomposition via $\mathrm{Li}_{2} \mathrm{~B}_{12} \mathrm{H}_{12}$, were realized under appropriate conditions, respectively. By applying a $\mathrm{H}_{2}$ pressure of 50 bar at $873 \mathrm{~K}$ or 10 bar at $700 \mathrm{~K}, \mathrm{LiBH}_{4}$ is forced to decompose into $\mathrm{Li}_{2} \mathrm{~B}_{12} \mathrm{H}_{12}$. In a lower pressure range of 0.1 to 10 bar at $873 \mathrm{~K}$ and $800 \mathrm{~K}$, the concurrence of both decomposition pathways is observed. Raman spectroscopy and ${ }^{11} \mathrm{~B}$ MAS NMR measurements confirm the formation of an intermediate $\mathrm{Li}_{2} \mathrm{~B}_{12} \mathrm{H}_{12}$ phase (mostly $\mathrm{Li}_{2} \mathrm{~B}_{12} \mathrm{H}_{12}$ adducts, such as dimers or trimers) and amorphous boron.

\section{Introduction}

The development of viable hydrogen storage materials is one of the key technologies to utilize hydrogen as a synthetic energy carrier to replace the limited fossil fuels that are in use today. Due to the high gravimetric $(18 \mathrm{wt} \%)$ and volumetric hydrogen density $\left(122 \mathrm{~kg} \mathrm{~m}^{-3}\right)$, lithium borohydride $\left(\mathrm{LiBH}_{4}\right)$ is currently one of the most discussed materials. ${ }^{1-5}$ On the example of $\mathrm{LiBH}_{4}$ the perspectives as well as the challenges of solid hydrogen storage become visible. $\mathrm{LiBH}_{4}$ melts at $550 \mathrm{~K}$ and decomposes into $\mathrm{LiH}$, boron and $\mathrm{H}_{2}$ according to the following reaction:

$$
\mathrm{LiBH}_{4} \rightarrow \mathrm{LiH}+\mathrm{B}+3 / 2 \mathrm{H}_{2}
$$

The reverse reaction has been observed at $873 \mathrm{~K}$ under 150 to 350 bar $\mathrm{H}_{2} \cdot{ }^{6,7}$ Recently, extensive efforts have been mainly made to destabilize the compound and to improve its reversibility. ${ }^{8-18}$ However, the decomposition and recombination mechanisms of $\mathrm{LiBH}_{4}$ have not been fully understood.

The overall reaction for the decomposition and recombination of $\mathrm{LiBH}_{4}$ can be expressed in reaction (1). Different reaction

\footnotetext{
${ }^{a}$ EMPA, Swiss Federal Laboratories for Materials Science and Technology, Hydrogen \& Energy, 8600 Dübendorf, Switzerland. E-mail: yigang.yan@empa.ch; Fax: + 415876540 22; Tel: + 41587654082

${ }^{b}$ Division of Chemistry and Chemical Engineering, California Institute of Technology, Pasadena, California 91125, USA

${ }^{c}$ International Research Center for Hydrogen Energy,

Kyushu University, Fukuoka 819-0395, Japan

${ }^{d}$ International Institute for Carbon-Neutral Energy Research,

Kyushu University, Fukuoka 819-0395, Japan

${ }^{e}$ Institute for Materials Research, Tohoku University,

Sendai 980-8577, Japan
}

pathways leading to the final products of $\mathrm{LiH}$, boron and $\mathrm{H}_{2}$ have been proposed. Based on the observation of $\mathrm{Li}_{2} \mathrm{~B}_{12} \mathrm{H}_{12}$ by Raman spectroscopy ${ }^{19}$ and ${ }^{11} \mathrm{~B}$ NMR measurements, ${ }^{20} \mathrm{LiBH}_{4}$ is considered to decompose according to reaction (2).

$$
\begin{aligned}
\mathrm{LiBH}_{4} & \rightarrow 5 / 6 \mathrm{LiH}+1 / 12 \mathrm{Li}_{2} \mathrm{~B}_{12} \mathrm{H}_{12}+13 / 12 \mathrm{H}_{2} \\
& \rightarrow \mathrm{LiH}+\mathrm{B}+3 / 2 \mathrm{H}_{2}
\end{aligned}
$$

Another pathway involving diborane $\left(\mathrm{B}_{2} \mathrm{H}_{6}\right)$ as an intermediate has been proposed based on the detection of $\mathrm{B}_{2} \mathrm{H}_{6}$ in the decomposition process of $\mathrm{LiBH}_{4}{ }^{21}$

$$
\mathrm{LiBH}_{4} \rightarrow \mathrm{LiH}+1 / 2 \mathrm{~B}_{2} \mathrm{H}_{6} \rightarrow \mathrm{LiH}+\mathrm{B}+3 / 2 \mathrm{H}_{2}
$$

Recent investigations also identified $\mathrm{Li}_{2} \mathrm{~B}_{12} \mathrm{H}_{12}$ as a product of the gas solid reaction between $\mathrm{B}_{2} \mathrm{H}_{6}$ and $\mathrm{LiBH}_{4}$ (reaction (4)). ${ }^{22}$ Since $\mathrm{B}_{2} \mathrm{H}_{6}$ was observed as an impurity gas in the dehydrogenation of $\mathrm{LiBH}_{4},{ }^{21} \mathrm{Li}_{2} \mathrm{~B}_{12} \mathrm{H}_{12}$ was proposed to be a by-product of reaction (1) during the decomposition of $\mathrm{LiBH}_{4}$.

$$
2 \mathrm{LiBH}_{4}+5 \mathrm{~B}_{2} \mathrm{H}_{6} \rightarrow \mathrm{Li}_{2} \mathrm{~B}_{12} \mathrm{H}_{12}+13 \mathrm{H}_{2}
$$

The dehydrogenation pathway is very crucial for the applicability of a hydrogen storage material. Stable intermediates such as $\mathrm{Li}_{2} \mathrm{~B}_{12} \mathrm{H}_{12}$ reduce the usable amount of hydrogen, as they show significant thermal stability that needs much higher temperatures for further decomposition to boron. ${ }^{23}$ Volatile intermediates such as $\mathrm{B}_{2} \mathrm{H}_{6}$ contaminate the $\mathrm{H}_{2}$ and may poison the fuel cell. The intermediates $\mathrm{Li}_{2} \mathrm{~B}_{12} \mathrm{H}_{12}$ and $\mathrm{B}_{2} \mathrm{H}_{6}$ also act as boron-sink, leading to the degradation in the reversibility of the dehydrogenation reaction. The thermodynamic parameters, i.e. the heat of reaction and the entropy of reaction, determine the working conditions. Vice versa, the reaction path is affected by the external conditions. Thus by 
applying suitable conditions (temperature and $\mathrm{H}_{2}$ external pressure), according to the thermodynamic parameters of the possible decomposition reactions, the most suitable reaction path may be selected. In the present study, we discuss and compare different decomposition pathways for $\mathrm{LiBH}_{4}$ according to the thermodynamic parameters and show experimental ways to realize them. This research provides new insights on understanding the dehydrogenation mechanism of $\mathrm{LiBH}_{4}$.

\section{Thermodynamic consideration}

Fig. 1 shows the energy levels of $\mathrm{LiBH}_{4}$ for the decomposition reaction involving the intermediate of $\mathrm{Li}_{2} \mathrm{~B}_{12} \mathrm{H}_{12}$. ${ }^{7,24,26}$ The reaction enthalpy of the transformation from $\mathrm{LiBH}_{4}$ into $\mathrm{LiH}$ and boron (reaction (1)) is determined to be $111 \mathrm{~kJ} \mathrm{~mol}^{-1}$ (or $74 \mathrm{~kJ} \mathrm{~mol}^{-1} \mathrm{H}_{2}$ ) by both experimental measurements ${ }^{7}$ and theoretical calculations. ${ }^{25} \mathrm{We}$ denote this as a process of direct decomposition since no stepwise reaction is involved. The reaction enthalpy of decomposition into $\mathrm{Li}_{2} \mathrm{~B}_{12} \mathrm{H}_{12}$ (reaction (2a)) is predicted to be $61 \mathrm{~kJ} \mathrm{~mol}^{-1}$ (or $56 \mathrm{~kJ} \mathrm{~mol}^{-1} \mathrm{H}_{2}$ ), ${ }^{26}$ which is approximately $50 \mathrm{~kJ} \mathrm{~mol}^{-1}$ (or $18 \mathrm{~kJ} \mathrm{~mol}^{-1} \mathrm{H}_{2}$ ) lower than that of the direct decomposition (reaction (1)). Experimentally, the formation of $\mathrm{Li}_{2} \mathrm{~B}_{12} \mathrm{H}_{12}$ has been observed by Raman spectroscopy and ${ }^{11} \mathrm{~B}$ MAS NMR. ${ }^{19,20}$ The direct decomposition (reaction (1)) into $\mathrm{LiH}$ and boron seems kinetically favored, whereas reaction (2a) via $\mathrm{Li}_{2} \mathrm{~B}_{12} \mathrm{H}_{12}$ is obviously kinetically hindered. ${ }^{27}$ To force the reaction via $\mathrm{Li}_{2} \mathrm{~B}_{12} \mathrm{H}_{12}$ and overcome the kinetic barrier, the temperature has to be high enough, such as $873 \mathrm{~K}$. At the same time, the direct decomposition has to be suppressed by applying an external pressure. A too high pressure on the other hand would stabilize the $\mathrm{LiBH}_{4}$ and prevent the decomposition. The appropriate experimental conditions were thus chosen according to the Van 't Hoff plots of the reactions in Fig. 2.

At a temperature of $873 \mathrm{~K}$, the equilibrium pressures $\left(P_{\mathrm{H} 2}\right)$ of reactions (1) and (2a) are estimated to be 38 and 2750 bar, respectively. Condition A with a $\mathrm{H}_{2}$ external pressure of 50 bar at $873 \mathrm{~K}$ was thus chosen, where reaction (1) should be suppressed and reaction (2) is allowed. On the other hand, $P_{\mathrm{H} 2}$ of reaction (2b) (i.e. the dissociation pressure of $\mathrm{Li}_{2} \mathrm{~B}_{12} \mathrm{H}_{12}$ )

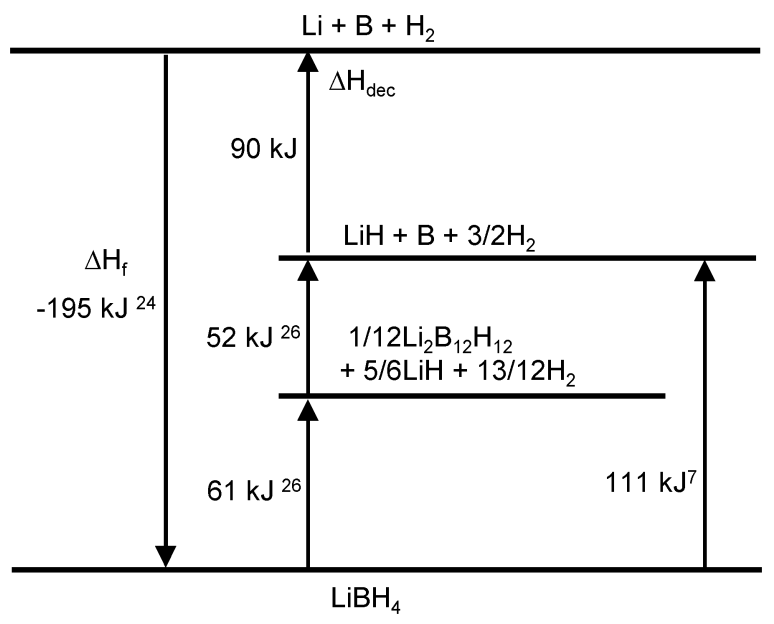

Fig. 1 Simplified schematic enthalpy diagram of the decomposition of $\mathrm{LiBH}_{4}$ involving the intermediate, neglecting the phase transitions.

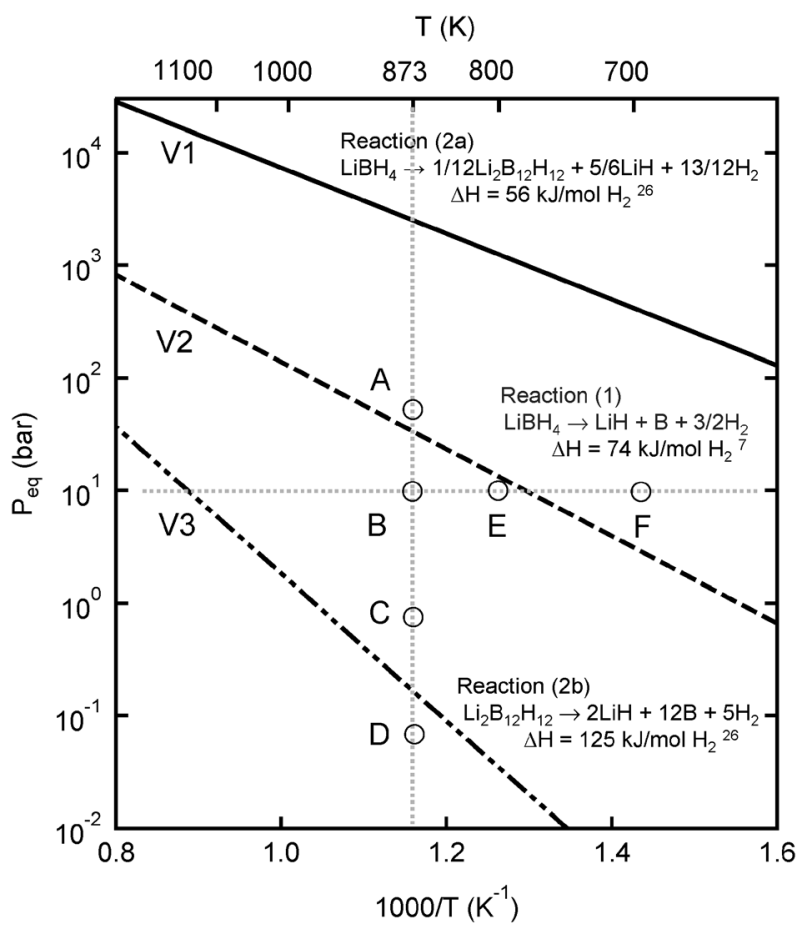

Fig. 2 Van 't Hoff curves for $\mathrm{LiBH}_{4}$ and $\mathrm{Li}_{2} \mathrm{~B}_{12} \mathrm{H}_{12}$ based on the experimental and/or calculated $\Delta H$ and $\Delta S$. V1, V2 and V3 represent the Van 't Hoff plots of reactions (2a), (1) and (2b), respectively. Conditions of A, B, C and D at $873 \mathrm{~K}$ with different $\mathrm{H}_{2}$ pressures of $50,10,1$ and 0.1 bar, and $\mathrm{E}$ and $\mathrm{F}$ with a $\mathrm{H}_{2}$ pressure of 10 bar at 800 and $700 \mathrm{~K}$, respectively, are chosen.

at $873 \mathrm{~K}$ is predicted to be 0.2 bar. Conditions $\mathrm{B}$ and $\mathrm{C}$, with applied $\mathrm{H}_{2}$ external pressures (i.e. 10 and 2 bar, respectively) between 38 and 0.2 bar at $873 \mathrm{~K}$, were thus chosen for comparison, where both reactions (1) and (2a) are thermodynamically possible and the $\mathrm{Li}_{2} \mathrm{~B}_{12} \mathrm{H}_{12}$ formed from reaction (2a) could be kept. Under condition $\mathrm{D}$, finally, i.e. in 0.1 bar $\mathrm{H}_{2}$ at $873 \mathrm{~K}$, the intermediate Li2B12H12 becomes unstable.

The temperature dependence of the decomposition reactions was also investigated by fixing the $\mathrm{H}_{2}$ external pressure at 10 bar while varying temperatures from 873 to $700 \mathrm{~K}$, symbolically denoted as conditions B, E and F in Fig. 2. Thermodynamically, the decomposition pathways at $\mathrm{E}$ and $\mathrm{F}$ are expected to be the same as those at $\mathrm{B}$ and $\mathrm{A}$, respectively.

The decomposition into $\mathrm{LiH}$ and $\mathrm{B}_{2} \mathrm{H}_{6}$ cannot be included in Fig. 2, as it does not involve hydrogen. Experimentally, only a low amount of $\mathrm{B}_{2} \mathrm{H}_{6}$ relative to the hydrogen released from $\mathrm{LiBH}_{4}$ has been detected. ${ }^{21}$ The amount of $\mathrm{B}_{2} \mathrm{H}_{6}$ released is even smaller when the decomposition of $\mathrm{LiBH}_{4}$ takes places in a $\mathrm{H}_{2}$ atmosphere. ${ }^{28} \mathrm{As} \mathrm{B}_{2} \mathrm{H}_{6}$ is unstable at elevated temperatures, it is difficult to detect. However, $\mathrm{B}_{2} \mathrm{H}_{6}$ or its monomer, $\mathrm{BH}_{3}$, may play a role in the decomposition of $\mathrm{LiBH}_{4}$ and the formation of $\mathrm{Li}_{2} \mathrm{~B}_{12} \mathrm{H}_{12}$. ${ }^{22,29}$

\section{Experimental section}

The starting material $\left(\mathrm{LiBH}_{4}\right.$, purity, 95\%) was purchased from Sigma-Aldrich Corp. The decomposition reactions of $\mathrm{LiBH}_{4}$ were carried out as follows: $1 \mathrm{~g}$ of $\mathrm{LiBH}_{4}$ was placed in a stainless steel reactor in a glove box filled with purified argon 
(dew point below $180 \mathrm{~K}$ ). The reactor containing the $\mathrm{LiBH}_{4}$ was connected to a Sieverts device for evacuation and loading of hydrogen. $\mathrm{LiBH}_{4}$ was dehydrogenated for $5 \mathrm{~h}$ under various thermal and pressure conditions as described above (except for the condition $\mathrm{F}$ which used $72 \mathrm{~h}$ duration for the reaction at $700 \mathrm{~K})$.

Samples for XRD measurements were filled into glass capillaries (diameter, $0.7 \mathrm{~mm}$; wall thickness, $0.01 \mathrm{~mm}$ ) and sealed in the glovebox. XRD measurements were performed using a Bruker D8 diffractometer and $\mathrm{Cu} \mathrm{K}_{\alpha}$ radiation $(\lambda=1.5418 \AA)$. The diffractometer is equipped with a Goebel mirror and a linear detector system (Vantec). Raman spectra at room temperature were obtained with a Bruker Senterra instrument of $5 \mathrm{~cm}^{-1}$ spectral resolution (spatial resolution $\approx 5 \mu \mathrm{m}$ ) using a $532 \mathrm{~nm}$ laser. Solid state magic angle spinning (MAS) nuclear magnetic resonance (NMR) spectra were obtained using a Bruker Avance $500 \mathrm{MHz}$ spectrometer with a wide bore $11.7 \mathrm{~T}$ magnet and employing a boron-free Bruker $4 \mathrm{~mm}$ CPMAS probe. The spectral frequency was $160.50 \mathrm{MHz}$ for ${ }^{11} \mathrm{~B}$ nucleus, and the NMR shifts are reported in parts per million (ppm) externally referenced to $\mathrm{BF}_{3} \cdot \mathrm{O}\left(\mathrm{CH}_{2} \mathrm{CH}_{3}\right)_{2}$ at $0 \mathrm{ppm}$.

\section{Results}

The XRD patterns of the samples after decomposition at $873 \mathrm{~K}$ and different $\mathrm{H}_{2}$ pressures are shown in Fig. 3. In sample A, a small amount of $\mathrm{LiH}$ in addition to the undecomposed $\mathrm{LiBH}_{4}$ is observed, indicating the partial decomposition of $\mathrm{LiBH}_{4}$. In samples B, C and D, the diffraction peaks of $\mathrm{LiBH}_{4}$ disappear and only those of $\mathrm{LiH}$ are observed with progressive increment in quantity. There are no diffraction peaks from the intermediate compound of $\mathrm{Li}_{2} \mathrm{~B}_{12} \mathrm{H}_{12}$, probably due to its amorphous state.

The Raman spectra of the decomposed samples are shown in Fig. 4. The bending and stretching modes of $\left[\mathrm{B}_{12} \mathrm{H}_{12}\right]^{2-}$ around 800 and $2500 \mathrm{~cm}^{-1}$, respectively, are observed in sample A. This observation proves the decomposition of $\mathrm{LiBH}_{4}$ into $\mathrm{Li}_{2} \mathrm{~B}_{12} \mathrm{H}_{12}$ under 50 bar $\mathrm{H}_{2}$ at $873 \mathrm{~K}$. However, the kinetics of decomposition into $\mathrm{Li}_{2} \mathrm{~B}_{12} \mathrm{H}_{12}$ under condition

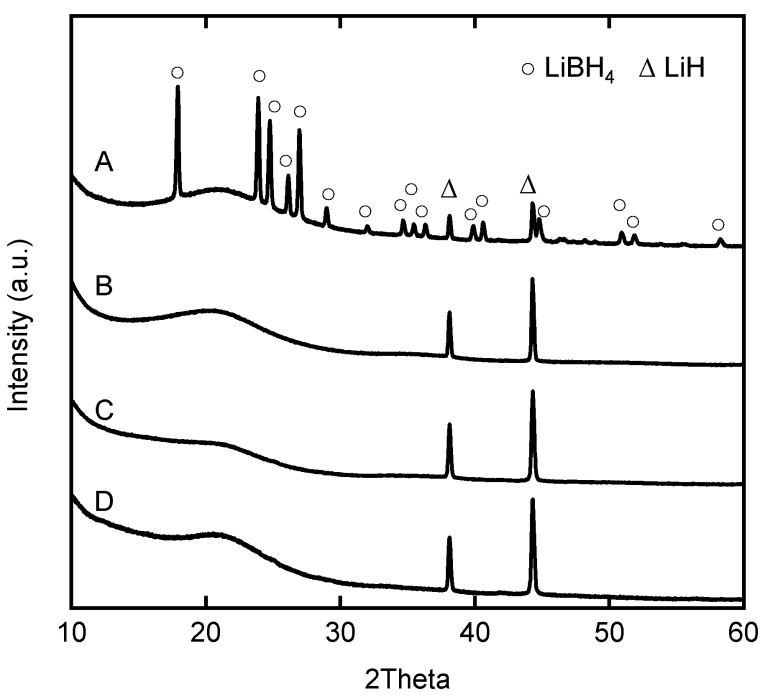

Fig. 3 XRD patterns of samples decomposed at $873 \mathrm{~K}$ in a $\mathrm{H}_{2}$ atmosphere of (A) 50 bar, (B) 10 bar, (C) 2 bar and (D) 0.1 bar.

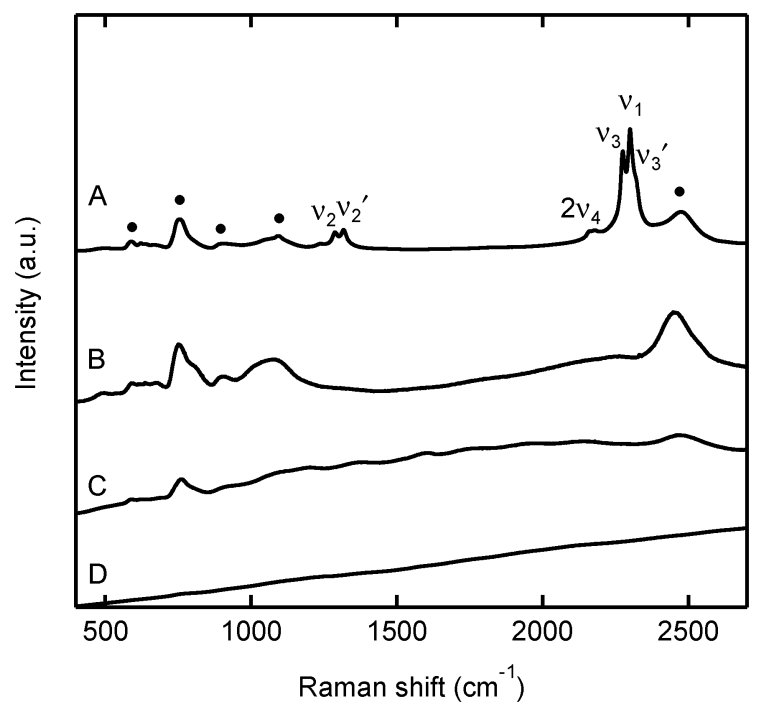

Fig. 4 Raman spectra of samples decomposed at $873 \mathrm{~K}$ in (A) 50 bar, (B) 10 bar, (C) 2 bar and (D) 0.1 bar. $\nu$ represents B-H vibration of $\left[\mathrm{BH}_{4}\right]^{-}$. Peaks $(\bullet)$ at $595,750,900$ and $1080 \mathrm{~cm}^{-1}$ are attributed to B-H vibrations of $\left[\mathrm{B}_{12} \mathrm{H}_{12}\right]^{2-}$, which are confirmed by ${ }^{11} \mathrm{~B}$ MAS NMR measurement in Fig. 5. B-B vibrations of amorphous boron are not observed by Raman spectroscopy.

A appears to be poor as its formation is in low quantity according to the Raman spectrum.

In sample $\mathrm{B}, \mathrm{B}-\mathrm{H}$ vibrations of $\left[\mathrm{BH}_{4}\right]^{-}$disappear and those of $\left[\mathrm{B}_{12} \mathrm{H}_{12}\right]^{2-}$ become stronger, indicating that a lower $\mathrm{H}_{2}$ pressure of 10 bar facilitates the decomposition of $\mathrm{LiBH}_{4}$ into $\mathrm{Li}_{2} \mathrm{~B}_{12} \mathrm{H}_{12}$. There are also no $\mathrm{B}-\mathrm{H}$ vibrations of $\left[\mathrm{BH}_{4}\right]^{-}$ observed in sample $\mathrm{C}$; however, the fading of $\mathrm{B}-\mathrm{H}$ vibrations of $\left[\mathrm{B}_{12} \mathrm{H}_{12}\right]^{2-}$ implies less $\mathrm{Li}_{2} \mathrm{~B}_{12} \mathrm{H}_{12}$ in sample $\mathrm{C}$, compared to sample B. No $\mathrm{B}-\mathrm{H}$ vibrations of $\left[\mathrm{BH}_{4}\right]^{-}$or $\left[\mathrm{B}_{12} \mathrm{H}_{12}\right]^{2-}$ are observed in sample D.

The decomposition products of $\mathrm{A}$ to $\mathrm{D}$ were further examined by using ${ }^{11} \mathrm{~B}$ MAS NMR measurements, as shown in Fig. 5. In sample $\mathrm{A}$, except the peak at $-41 \mathrm{ppm}$ from undecomposed $\mathrm{LiBH}_{4}$, other two peaks are observed: a sharp one at $-15.6 \mathrm{ppm}$ and a board one at $-12 \mathrm{ppm}$. The former corresponds well with the reference of $\mathrm{Li}_{2} \mathrm{~B}_{12} \mathrm{H}_{12}$, and the latter is considered to result from combination of $\mathrm{Li}_{2} \mathrm{~B}_{12} \mathrm{H}_{12}$ units such as dimers or trimers. ${ }^{30}$ Then, the NMR results confirm the decomposition of $\mathrm{LiBH}_{4}$ via $\mathrm{Li}_{2} \mathrm{~B}_{12} \mathrm{H}_{12}$ (reaction (2)) under condition $\mathrm{A}$.

In samples of $\mathrm{B}, \mathrm{C}$ and $\mathrm{D}$ asymmetric peaks at around $-12 \mathrm{ppm}$ in addition to small peaks at $-41 \mathrm{ppm}$ from $\mathrm{LiBH}_{4}$ are observed. These asymmetric peaks can be deconvoluted into peaks at -12 ppm of $\mathrm{Li}_{2} \mathrm{~B}_{12} \mathrm{H}_{12}$ adducts and peaks at +4 ppm that can be attributed to amorphous boron (Fig. 6). Similarly, the observation of $\mathrm{Li}_{2} \mathrm{~B}_{12} \mathrm{H}_{12}$ related species in samples $\mathrm{B}$ and $\mathrm{C}$ agrees well with the results of Raman spectra in Fig. 4. The formation of amorphous boron in samples B and $\mathrm{C}$ is considered to result from the direct decomposition of $\mathrm{LiBH}_{4}$ according to reaction (1) rather than the decomposition of $\mathrm{Li}_{2} \mathrm{~B}_{12} \mathrm{H}_{12}$, since $\mathrm{Li}_{2} \mathrm{~B}_{12} \mathrm{H}_{12}$ is theoretically predicted to be stable under conditions $\mathrm{B}$ and $\mathrm{C},{ }^{26}$ as shown in Fig. 2. The stability of $\mathrm{Li}_{2} \mathrm{~B}_{12} \mathrm{H}_{12}$ is also experimentally verified, i.e. the $\mathrm{B}-\mathrm{H}$ vibrations of $\left[\mathrm{B}_{12} \mathrm{H}_{12}\right]^{2-}$ (sample $\left.\mathrm{B}\right)$ do not decay with time, as displayed in Fig. 7. The coexistence of amorphous 


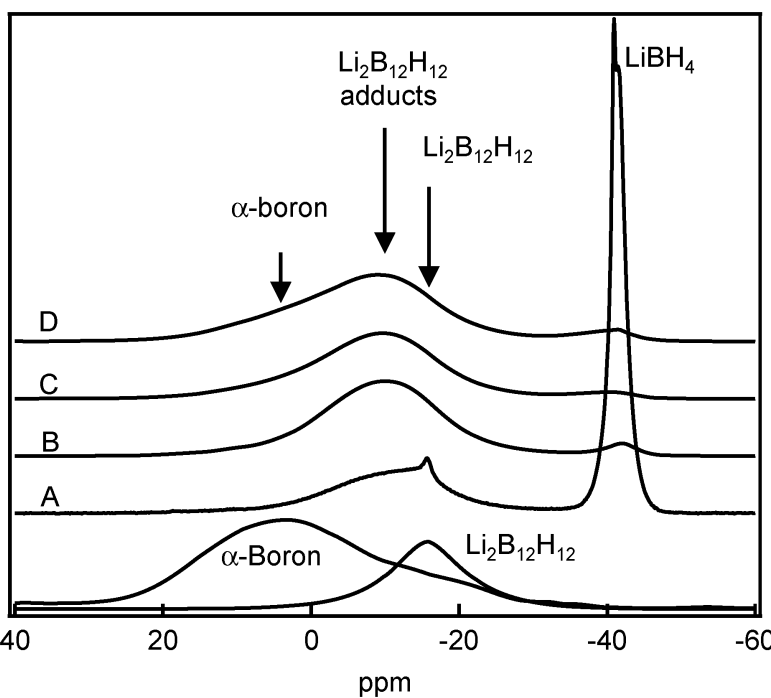

Fig. $5{ }^{11}$ B MAS NMR spectra of samples A to D. Elemental boron in amorphous state ( $\alpha$-boron from Sigam-Aldrich) and $\mathrm{Li}_{2} \mathrm{~B}_{12} \mathrm{H}_{12}$ were used as the references. $\mathrm{Li}_{2} \mathrm{~B}_{12} \mathrm{H}_{12}$ adducts, such as dimers or trimers, possibly originate from the combination of $\mathrm{Li}_{2} \mathrm{~B}_{12} \mathrm{H}_{12}$ units. ${ }^{30}$
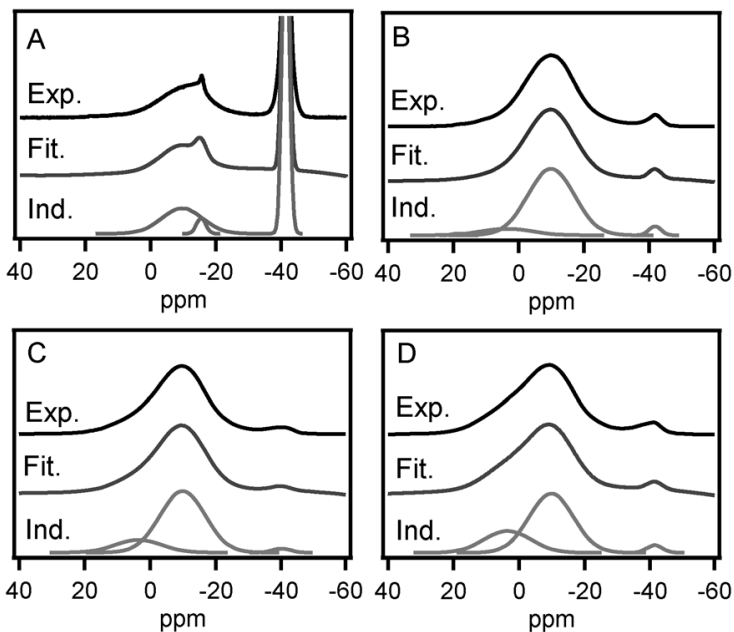

Fig. 6 (A-D) Deconvolution of ${ }^{11}$ B MAS NMR spectra for samples A to D. Experimental peaks are in black, fitted in dark gray and individual components in light gray.

boron and $\mathrm{Li}_{2} \mathrm{~B}_{12} \mathrm{H}_{12}$ adducts in samples $\mathrm{B}$ and $\mathrm{C}$ indicates the occurrence of both reactions (1) and (2a) under conditions B and $\mathrm{C}$, respectively. The amorphous boron in sample $\mathrm{D}$ may be attributed to both reactions (1) and (2b).

The amounts of boron in different chemical states, depending on the pressure in the decomposition of $\mathrm{LiBH}_{4}$ at $873 \mathrm{~K}$, are displayed in Fig. 8. At an external pressure of 50 bar, only $1 / 3$ of $\left[\mathrm{BH}_{4}\right]^{-}$transfers to $\left[\mathrm{B}_{12} \mathrm{H}_{12}\right]^{2-}$ and no amorphous boron is observed. In the pressure range of 10 to $0.1 \mathrm{bar},\left[\mathrm{BH}_{4}\right]^{-}$nearly completely decomposes into $\left[\mathrm{B}_{12} \mathrm{H}_{12}\right]^{2-}$ and amorphous boron. The lower the external pressure, the more efficient the $\mathrm{LiBH}_{4}$ decomposition, the smaller the amount of $\left[\mathrm{B}_{12} \mathrm{H}_{12}\right]^{2-}$, the higher the amount of amorphous boron.

The temperature dependence of the decomposition of $\mathrm{LiBH}_{4}$ at the external pressure of 10 bar $\mathrm{H}_{2}$ was investigated, and the decomposition products at different temperatures of

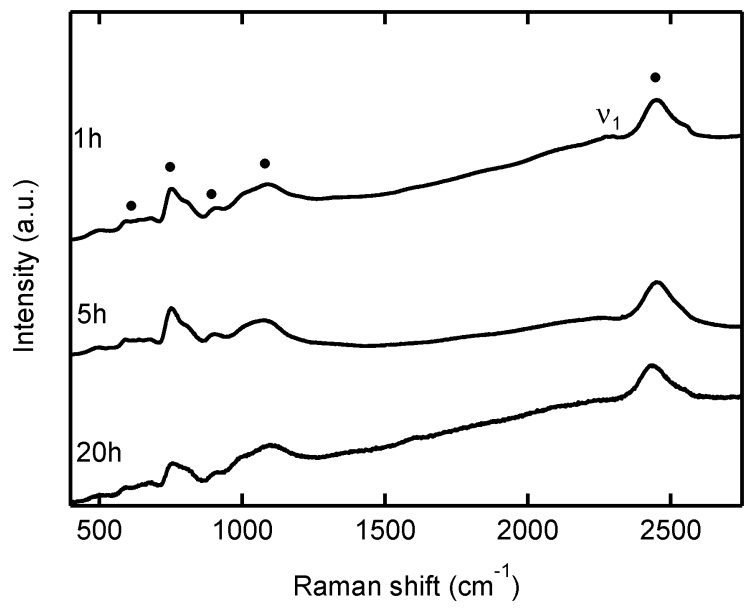

Fig. 7 Raman spectra of $\mathrm{LiBH}_{4}$ kept in a $\mathrm{H}_{2}$ atmosphere of 10 bar at $873 \mathrm{~K}$ for 1,5 and $20 \mathrm{~h}$ respectively. $\nu$ represents $\mathrm{B}-\mathrm{H}$ vibration of $\left[\mathrm{BH}_{4}\right]^{-}$, and the close circles $(\bullet)$ correspond to those of $\left[\mathrm{B}_{12} \mathrm{H}_{12}\right]^{2-}$.

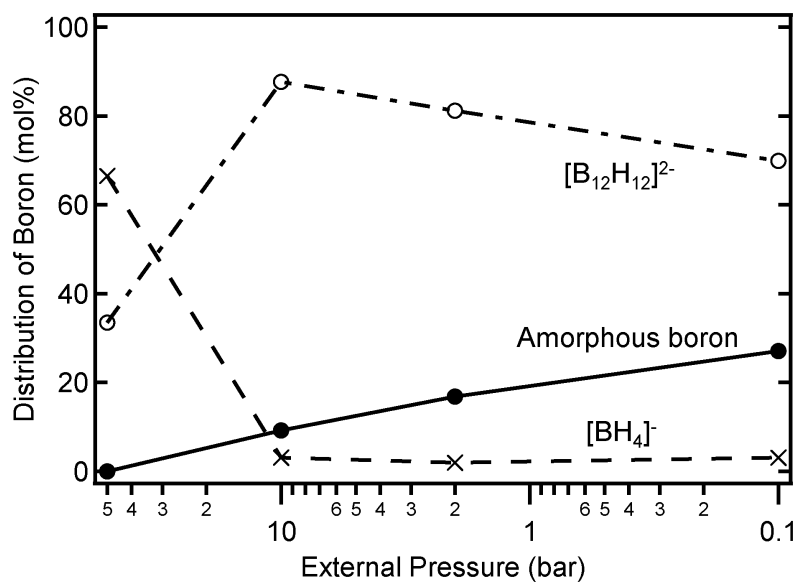

Fig. 8 The amounts of boron in different chemical states of $\left[\mathrm{BH}_{4}\right]^{-}$, $\left[\mathrm{B}_{12} \mathrm{H}_{12}\right]^{2-}$ and amorphous boron, respectively, after the decomposition of $\mathrm{LiBH}_{4}$ as a function of the external pressure at $873 \mathrm{~K}$. The amounts were calculated based on the peak areas of individual components in Fig. 6.

$873 \mathrm{~K}$ (B), $773 \mathrm{~K}$ (E) and $700 \mathrm{~K}$ (F) are examined by XRD and Raman spectroscopy, as shown in Fig. 9 and 10, respectively. In samples $\mathrm{B}$ and $\mathrm{E}$, similar results are observed, i.e. $\mathrm{LiH}$ is identified as the only phase by XRD and $\mathrm{B}-\mathrm{H}$ vibrations of $\left[\mathrm{B}_{12} \mathrm{H}_{12}\right]^{2-}$ by Raman spectroscopy. This suggests the similar decomposition products in samples B and E. In sample F, small diffraction peaks of $\mathrm{LiH}$ observed by XRD and weak $\mathrm{B}-\mathrm{H}$ vibrations of $\left[\mathrm{B}_{12} \mathrm{H}_{12}\right]^{2-}$ by Raman spectroscopy indicate the partial decomposition of $\mathrm{LiBH}_{4}$ into $\mathrm{Li}_{2} \mathrm{~B}_{12} \mathrm{H}_{12}$, similar to sample A. Similar decomposition products obtained in samples $\mathrm{B}$ and $\mathrm{E}$ and in samples $\mathrm{A}$ and $\mathrm{F}$, respectively, prove the consistence of thermodynamic consideration above.

\section{Conclusion and discussion}

Two different dehydrogenation pathways of $\mathrm{LiBH}_{4}$, i.e. direct decomposition into boron according to reaction (1) and decomposition via $\mathrm{Li}_{2} \mathrm{~B}_{12} \mathrm{H}_{12}$ into boron according to reaction (2), were 


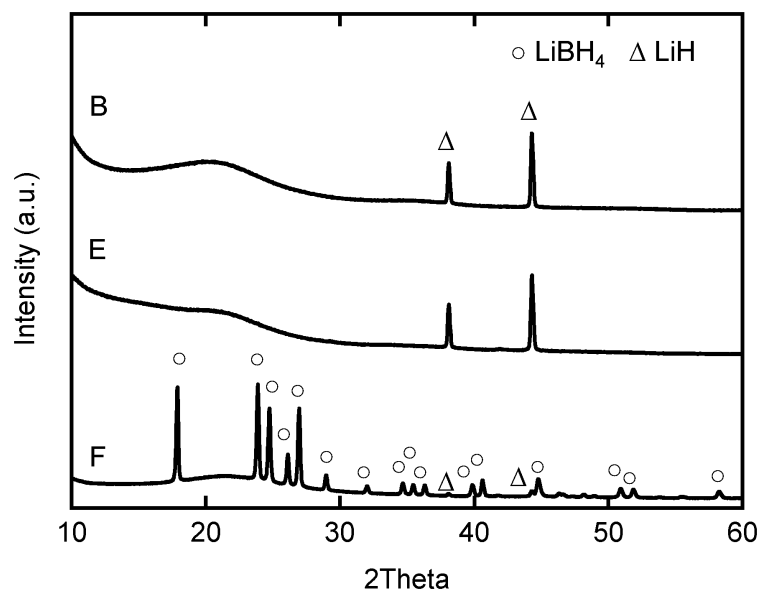

Fig. 9 XRD patterns of samples decomposed in a $\mathrm{H}_{2}$ atmosphere of 10 bar at (B) $873 \mathrm{~K}$, (E) $773 \mathrm{~K}$, and (F) $700 \mathrm{~K}$.

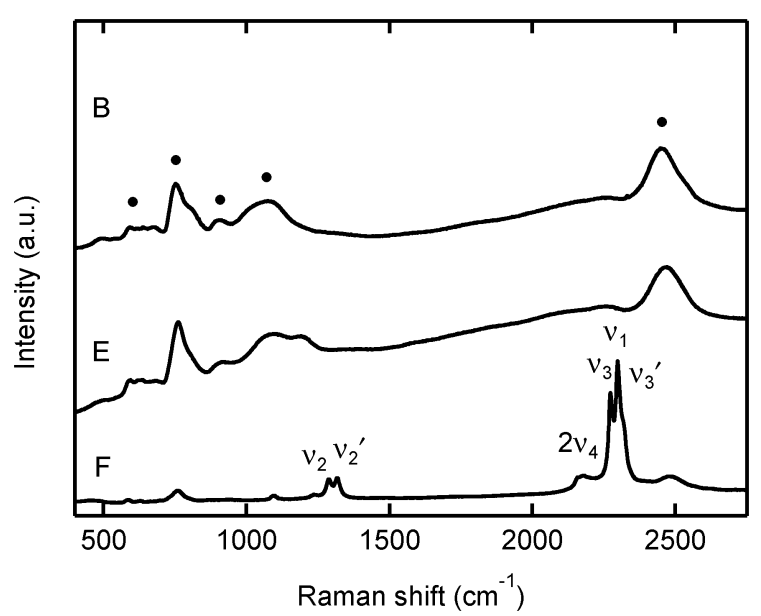

Fig. 10 Raman spectra of samples decomposed in a $\mathrm{H}_{2}$ atmosphere of 10 bar at (B) $873 \mathrm{~K}$, (E) $773 \mathrm{~K}$, and (F) $700 \mathrm{~K}$. $\nu$ represents B-H vibration of $\left[\mathrm{BH}_{4}\right]^{-}$, and the close circles $(-)$correspond to those of $\left[\mathrm{B}_{12} \mathrm{H}_{12}\right]^{2-}$.

discussed and realized by choosing appropriate experimental conditions. (a) Under conditions between plots V1 and V2 in Fig. 2, $\mathrm{LiBH}_{4}$ is forced to decompose into $\mathrm{Li}_{2} \mathrm{~B}_{12} \mathrm{H}_{12}$, and the direct decomposition into boron is thermodynamically suppressed. (b) Under conditions between plots V2 and V3, the occurrence of both the decomposition into $\mathrm{Li}_{2} \mathrm{~B}_{12} \mathrm{H}_{12}$ and direct decomposition into boron is observed. The formed $\mathrm{Li}_{2} \mathrm{~B}_{12} \mathrm{H}_{12}$ is stable and tends to oligomerize into dimers or trimers. Lower $\mathrm{H}_{2}$ pressure facilitates the direct decomposition of $\mathrm{LiBH}_{4}$ into boron. (c) Under conditions below plot V3, both pathways are possible. Boron (and $\mathrm{LiH}$ ) will be the final decomposition product.

Due to the high equilibrium pressure of reaction (2a), a two-step decomposition involving $\mathrm{Li}_{2} \mathrm{~B}_{12} \mathrm{H}_{12}$ has not been observed in pressure composition isotherms. Mauron et al. measured isotherms from a starting $\mathrm{H}_{2}$ pressure of 20 bar at a temperature in the range of 686 to $790 \mathrm{~K} .^{7}$ The starting conditions are well below the Van 't Hoff curve (V1) in Fig. 2. Under the starting conditions, $\mathrm{LiBH}_{4}$ is unstable against the decomposition via $\mathrm{Li}_{2} \mathrm{~B}_{12} \mathrm{H}_{12}$. This means that $\mathrm{LiBH}_{4}$ starts to release hydrogen before the plateau pressure described by $\mathrm{V} 2$ is reached, which could be attributed to the partial decomposition according to reaction (2a).

Under the conditions $\mathrm{A}\left(50\right.$ bar $\left.\mathrm{H}_{2}, 873 \mathrm{~K}\right)$ and $\mathrm{F}$ (10 bar $\mathrm{H}_{2}, 700 \mathrm{~K}$ ), the decomposition of $\mathrm{LiBH}_{4}$ via $\mathrm{Li}_{2} \mathrm{~B}_{12} \mathrm{H}_{12}$ suffers from the kinetic barriers, i.e. only small amounts of $\mathrm{Li}_{2} \mathrm{~B}_{12} \mathrm{H}_{12}$ are observed and the majorities of $\mathrm{LiBH}_{4}$ are unreacted. Lowering the $\mathrm{H}_{2}$ external pressure to the range of 10 to 0.1 bar at $873 \mathrm{~K}$ significantly facilitates the decomposition of $\mathrm{LiBH}_{4}$ (Fig. 3-6 and 8), indicating a strong kinetic influence of the external pressure on the decomposition reaction. On the other hand, when the $\mathrm{H}_{2}$ pressure is decreased to the range of 10 to 0.1 bar, the decomposition of $\mathrm{LiBH}_{4}$ to amorphous boron (reaction (1)) is thermodynamically permitted, as shown in Fig. 2. The formation of amorphous boron could subsequently catalyze the decomposition of $\mathrm{LiBH}_{4}$ via $\mathrm{Li}_{2} \mathrm{~B}_{12} \mathrm{H}_{12}$ by working as the nucleation seeds, ${ }^{27}$ resulting in the formation of the large amounts of $\mathrm{Li}_{2} \mathrm{~B}_{12} \mathrm{H}_{12}$ under conditions $\mathrm{B}, \mathrm{C}, \mathrm{D}$ and $\mathrm{E}$.

The poor kinetics of reaction (2a) probably originates from the phenomenological clustering process from $\left[\mathrm{BH}_{4}\right]^{-}$to $\left[\mathrm{B}_{12} \mathrm{H}_{12}\right]^{2-}$. This process involves twelve individual $\left[\mathrm{BH}_{4}\right]^{-}$ units to deliver the necessary amount of boron, and is thus restricted by mass transport., ${ }^{5,12,13}$ Recently, Hoang and Van de Walle proposed a decomposition mechanism of $\mathrm{LiBH}_{4}$ that involves mass transport mediated by native defects. ${ }^{29}$ In this mechanism, $\mathrm{LiBH}_{4}$ releases borane $\left(\mathrm{BH}_{3}\right)$ at the surface or interface, leaving the negatively charged hydrogen interstitial $\left(\mathrm{H}_{\mathrm{i}}^{-}\right)$in the material, which then acts as the nucleation site for $\mathrm{LiH}$ formation. The diffusion of $\mathrm{H}_{\mathrm{i}}{ }^{-}$in the bulk $\mathrm{LiBH}_{4}$ is considered to be the rate-limiting step in the decomposition kinetics. $\mathrm{BH}_{3}$ could subsequently decompose into $\mathrm{B}$ and $\mathrm{H}_{2}$, or dimerize to form diborane $\left(\mathrm{B}_{2} \mathrm{H}_{6}\right) .{ }^{29} \mathrm{Li}_{2} \mathrm{~B}_{12} \mathrm{H}_{12}$ may be formed from the further polymerization of the borane species and/or the reaction with residual $\mathrm{LiBH}_{4}{ }^{22}$

$\left[\mathrm{B}_{12} \mathrm{H}_{12}\right]^{2-}$ containing species have also been identified among the decomposition compounds of other borohydrides such as $\mathrm{Mg}\left(\mathrm{BH}_{4}\right)_{2}$ and $\mathrm{Ca}\left(\mathrm{BH}_{4}\right)_{2} \cdot{ }^{20,31}$ A general statement however is not viable. As for the alanates, there is no general decomposition route. In the case of $\mathrm{LiBH}_{4}$, the formation of the stable intermediate may be partially circumvented due to kinetic reasons, i.e. if a competing decomposition route is favoured by its faster kinetics. To avoid the formation of unwanted $\left[\mathrm{B}_{12} \mathrm{H}_{12}\right]^{2-}$ containing intermediates, additives such as $\mathrm{MgH}_{2}, \mathrm{YH}_{3}, \mathrm{CeH}_{2}$ or $\mathrm{Al}$ in an applied $\mathrm{H}_{2}$ atmosphere of 2 to 10 bar have been used to enable different decomposition routes. ${ }^{8,11,12,32-38}$ These external pressures are sufficient to prevent reactions (1) and (2b), while the formation of $\mathrm{Li}_{2} \mathrm{~B}_{12} \mathrm{H}_{12}$ according to reaction (2a) is still thermodynamically possible. The role of the additive is to bind the boron in the form of stable borides (e.g. $\mathrm{MgB}_{2}, \mathrm{YB}_{4}, \mathrm{CeB}_{6}$ or $\mathrm{AlB}_{2}$ ). Higher hydrogen pressures, which will slow the decomposition of $\mathrm{LiBH}_{4}$, are found to be more favourable for the formation of borides. ${ }^{39,40}$

In the present work, we have demonstrated that the knowledge of the thermodynamic properties of the hydride and its possible decomposition products and intermediates allows flexibility in selection of the decomposition pathway by tuning the external parameters such as pressure and temperature. In this way, it is possible that, unwanted by-products or boron sinks that prevent reversibility can be circumvented. 


\section{Acknowledgements}

Financial support from the Swiss National Science Foundation (SNF 200021_129603/1), from the Korea Research Council of Fundamental Science and Technology and by a grant from Switzerland through the Swiss Contribution to the enlarged European Union is gratefully appreciated. S.-J. H. kindly acknowledges the partial support from the U.S. Department of Energy (DOE), Office of Energy Efficiency and Renewable Energy, through the Hydrogen, Fuel Cells \& Infrastructure Technologies Program under contract number DE-AI-0105EE11105 (JPL-Caltech). The NMR facility at Caltech was supported by the National Science Foundation (NSF) under Grant Number 9724240 and partially supported by the MRSEC Program of the NSF under Award Number DMR520565. S. O. kindly acknowledges the support by "funding Program for Next Generation World-Leading Researchers (No. GR008)" and "ICC-IMR".

\section{Notes and references}

1 S. Orimo, Y. Nakamori, J. R. Eliseo, A. Züttel and C. M. Jensen, Chem. Rev., 2007, 107, 4111.

2 P. Chen and M. Zhu, Mater. Today, 2008, 11, 36.

3 J. Graetz, Chem. Soc. Rev., 2009, 38, 73.

4 U. Eberle, M. Felderhoff and F. Schüth, Angew. Chem., Int. Ed., 2009, 48, 6608.

5 H.-W. Li, Y. Yan, S. Orimo, A. Züttel and C. M. Jensen, Energies (Basel, Switz.), 2011, 4, 185.

6 S. Orimo, Y. Nakamori, G. Kitahara, K. Miwa, N. Ohba, S. Towata and A. Züttel, J. Alloys Compd., 2005, 404-406, 427.

$7 \mathrm{Ph}$. Mauron, F. Buchter, O. Friedrichs, A. Remhof, M. Bielmann, C. N. Zwicky and A. Züttel, J. Phys. Chem. C, 2008, 112, 906.

8 J. J. Vajo, S. L. Skeith and F. Mertens, J. Phys. Chem. B, 2005, 109, 3719.

9 M. Au, A. Jurgensen and K. Zeigler, J. Phys. Chem. B, 2006, 110, 26482. 10 X. B. Yu, D. M. Grant and G. S. Walker, Chem. Commun., 2006, 3906.

11 U. Bösenberg, S. Doppiu, L. Mosegaard, G. Barkhordarian, N. Eigen, A. Borgschulte, R. T. Jensen, Y. Cerenius, O. Gutfleisch, T. Klassen, M. Dornheim and R. Bormann, Acta Mater., 2007, 55, 3951.

12 J. Yang, A. Sudik and C. Wolverton, J. Phys. Chem. C, 2007, 111, 19134.

13 A. F. Gross, J. J. Vajo, S. L. Van Atta and G. L. Olson, J. Phys. Chem. C, 2008, 112, 5651.

14 X. F. Wan, T. Markmaltree, W. Obsborn and L. L. Shaw, J. Phys. Chem. C, 2008, 112, 18232.

15 E. A. Nickels, M. O. Jones, W. I. F. David and S. R. Johnson, Angew. Chem., Int. Ed., 2008, 47, 2817.

16 T. K. Nielsen, U. Bösenberg, R. Gosalawit, M. Dornheim, Y. Cerenius, F. Besenbacher and T. R. Jesen, ACS Nano, 2010, 4, 3903.
17 P. Ngene, M. van Zwienen and P. E. de Jongh, Chem. Commun., 2010, 46, 8201.

18 X. Liu, D. Peaslee, Z. C. Jost, T. F. Baumann and E. Majzoub, Chem. Mater., 2011, 23, 1331

19 S. Orimo, Y. Nakamori, N. Ohba, K. Miwa, M. Aoki, S. Towata and A. Züttel, Appl. Phys. Lett., 2006, 89, 021920.

20 S. J. Hwang, R. C. Bowman, J. W. Reiter, J. Rijssenbeek, G. L. Soloveichik, J.-C. Zhao, H. Kabbour and C. C. Ahn, J. Phys. Chem. C, 2008, 112, 3164.

21 S. Kato, M. Bielmann, A. Borgschulte, V. Zakaznova-Herzog, A. Remhof, S. Orimo and A. Züttel, Phys. Chem. Chem. Phys., $2010,12,10950$.

22 O. Friedrichs, A. Remhof, S.-J. Hwang and A. Züttel, Chem. Mater., 2010, 2, 3265.

23 E. L. Muetterties, J. H. Balthis, Y. T. Chia, W. H. Knoth and H. C. Miller, Inorg. Chem., 1964, 3, 444.

24 M. B. Smith and G. E. Bass, J. Chem. Eng. Data, 1963, 8, 342.

25 K. Miwa, N. Ohba, S. Towata, Y. Nakamori and S. Orimo, Phys. Rev. B: Condens. Matter Mater. Phys., 2004, 69, 245120.

26 N. Ohba, K. Miwa, M. Aoki, T. Noritake, S. Towata, Y. Nakamori and S. Orimo, Phys. Rev. B: Condens. Matter Mater. Phys., 2006, 74, 075110.

27 F. Pendolino, Ph. Mauron, A. Borgschulte and A. Züttel, J. Phys. Chem. C, 2009, 113, 17231.

28 A. Borgschutle, E. Callini, B. Probst, A. Jain, S. Kato, O. Friedrichs, A. Remhof, M. Bielmann, A. J. Ramirez-Cuesta and A. Züttel, J. Phys. Chem. C, 2011, 115, 17220.

29 K. Hoang and C. G. Van de Walle, Int. J. Hydrogen Energy, 2012, 37, 5825 .

30 S.-J. Hwang, Jr., R. C. Bowman, C. Kim, J. A. Zan and J. W. Reiter, J. Anal. Sci. Technol., 2011, 2, A165.

31 V. Stavila, J.-H. Her, W. Zhou, S.-J. Hwang, C. Kim, L. A. M. Ottley and T. J. Udovic, J. Solid State Chem., 2012, 183, 1133.

32 A. Remhof, O. Friedrichs, F. Buchter, Ph. Mauron, J. W. Kim, K. H. Oh, A. Buchsteiner, D. Wallacher and A. Züttel, J. Alloys Compd., 2009, 1-2, 654.

33 X.-D. Kang, P. Wang, L.-P. Ma and H.-M. Cheng, Appl. Phys. A: Solid Surf., 2009, 89, 963.

34 J. W. Kim, O. Friedrichs, J.-P. Ahn, D. H. Kim, S. C. Kim, A. Remhof, H.-S. Chung, J. Lee, J.-H. Shim, Y. W. Cho, A. Züttel and K. H. Oh, Scr. Mater., 2009, 60, 1089.

35 Y. J. Choi, J. Lu, H. Y. Sohn, Z. Z. Fang, C. Kim, R. C. Bowman and S.-J. Hwang, J. Phys. Chem. C, 2011, 115, 6048.

36 U. Bösenberg, D. B. Ravnsbæk, H. Hagemann, V. D'Anna, C. B. Minella, C. Pistidda, W. van Beek, T. R. Jensen, R. Bormann and M. Dornheim, J. Phys. Chem. C, 2010, 114, 15212.

37 J.-H. Shim, J.-H. Lim, S.-U. Rather, Y.-S. Lee, R. Daniel, Y. Kim, D. Book and Y. W. Cho, J. Phys. Chem. Lett., 2010, 1, 59.

$38 \mathrm{Ph}$. Mauron, M. Bielmann, A. Remhof, A. Züttel, J.-H. Shim and Y. W. Cho, J. Phys. Chem. C, 2010, 114, 16801.

39 Y. Yan, H.-W. Li, H. Maekawa, K. Miwa, S. Towata and S. Orimo, J. Phys. Chem. C, 2011, 115, 19419.

40 K.-B. Kim, J.-H. Shim, Y. W. Cho and K. H. Oh, Chem. Commun., 2011, 47, 9831. 